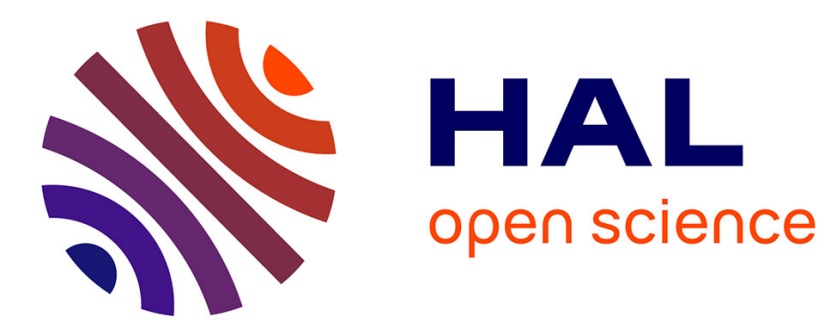

\title{
Shopping to save: green consumerism and the struggle for northern Maine
}

\author{
Blake Harrison
}

\section{To cite this version:}

Blake Harrison. Shopping to save: green consumerism and the struggle for northern Maine. cultural geographies, 2006, 13 (3), pp.395-420. 10.1191/1474474006eu365oa . hal-00572194

\section{HAL Id: hal-00572194 \\ https://hal.science/hal-00572194}

Submitted on 1 Mar 2011

HAL is a multi-disciplinary open access archive for the deposit and dissemination of scientific research documents, whether they are published or not. The documents may come from teaching and research institutions in France or abroad, or from public or private research centers.
L'archive ouverte pluridisciplinaire HAL, est destinée au dépôt et à la diffusion de documents scientifiques de niveau recherche, publiés ou non, émanant des établissements d'enseignement et de recherche français ou étrangers, des laboratoires publics ou privés. 


\title{
Shopping to save: green consumerism and the struggle for northern Maine
}

\author{
Blake Harrison \\ Department of Geography, Southern Connecticut University
}

\begin{abstract}
Between 2001 and 2003, Roxanne Quimby - then the sole owner of a natural personal-care products company named Burt's Bees - invested millions of dollars of her company's profits in tens of thousands of acres of forestland in northern Maine. Her intention was to donate that land to the United States government on behalf of a controversial national park proposed for the region-the Maine Woods National Park. Quimby's actions set off sharp debates between policy makers, environmentalists and residents of northern Maine. As this article suggests, those debates were informed in part by their association with green consumerism. When consumers purchase 'environmentally friendly' products like those made by Burt's Bees, they typically envision their actions as having positive consequences for places associated directly with the production and consumption of that product. In this case, however, profits from a green consumer product were reinvested outside its immediate commodity chain, thereby implicating green-consumer decisions in a politics of identity and landscape control beyond that product's lifecycle. This paper explores that process, suggesting that even the most well-intended consumer choices can carry social and environmental consequences into new and perhaps unexpected terrain. When we shop to save, we can never be quite certain of what it is that we are saving.
\end{abstract}

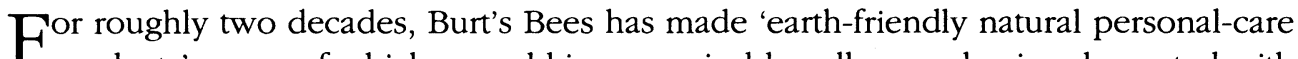
products', many of which are sold in recognizable yellow packaging decorated with a bearded man's face (Figure 1). From lip balm and soap to cosmetics and face cream, Burt's Bees products have become immensely popular among some consumers, and the company has become a highly successful, multi-million-dollar venture. You can find Burt's Bees products fairly easily in natural foods stores, pharmacies and department stores across the United States. You will not find them so easily, however, in northern Maine. This article explains the significance of this absence, both for those with an interest in northern New England's forested landscape and for those with an interest in the social and environmental consequences of consumer spending.

In some respects, the absence of Burt's Bees in northern Maine may not be all that surprising. Like other 'natural care' companies, Burt's Bees makes products that tend to be more expensive than conventional brands. Perhaps these products simply cost too much for residents of the state's forested interior (the 'Maine Woods') to afford; jobs in 


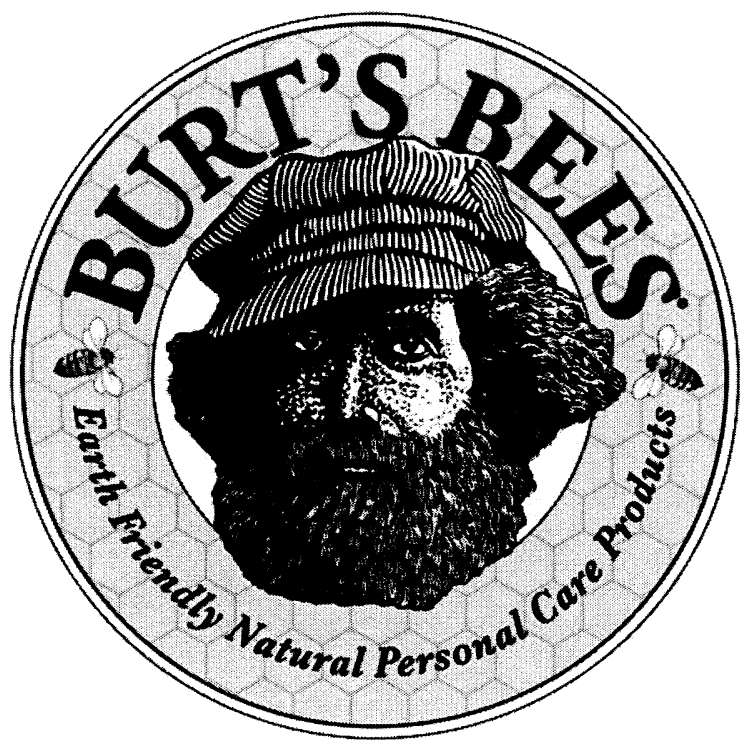

FIGURE 1 Rather than using glamorous models or glittering imagery, Burt's Bees has traditionally chosen a more natural, rustic and earthy look for their packaging, thereby reinforcing the company's associations with 'earth-friendly' practices. (Used by permission.)

logging and wood-products manufacturing have been disappearing from here for decades, and many residents struggle daily to make ends meet. Yet surely this is not true for everyone in northern Maine. And surely it is not true for many of the tourists who visit the Maine Woods to hike, fish, hunt, snowmobile and cross-country ski. Indeed, specialty stores and gift shops in area towns often carry higher-priced items aimed at the tourist market, so why not Burt's Bees? What is more, Burt's Bees got its homespun start in a backwoods cabin not far from the same towns whose merchants fail to carry its products today. Although the company has since moved its headquarters out of Maine, some might think its local ties would earn it a place on local shelves. But apparently, it does not.

What, then, explains the absence of Burt's Bees products in northern Maine?

The answer to that question has less to do with the company's prices than with its former support for a controversial proposal to create a 3.2-million-acre national park in northern Maine, the Maine Woods National Park (MWNP). ${ }^{1}$ Beginning in 2001, Burt's Bees co-founder and then owner, Roxanne Quimby, put her company's name and profits, as well as her own personal fortune, in the service of the proposed MWNP. Within a couple of years, she had spent millions of dollars on tens of thousands of acres of largely unsettled forestland in northern Maine, all of which she hoped to donate some day to the National Park Service (NPS), the federal agency responsible for managing the nation's parks. Her land would be a gift to the American public, she stated - the same public who made her company so successful. For a time, Quimby's efforts helped put the MWNP in the national spotlight, and thousands from Maine and 
beyond rallied to the cause. But thousands, too, rallied against it. This was particularly true in the logging and mill towns of northern Maine, where a national park was viewed widely as a threat to the region's economy, landscape and cultural identity. Yet whether one supported or opposed the park, there was one thing on which everyone could agree: the sale of lip balms and hand creams now had a great deal to do with the future of the Maine Woods.

This article explores links between the sale of Burt's Bees and the proposed MWNP as a means for thinking critically about the consequences that can flow from even the most well-intended consumer choices. By marketing itself as an 'environmentally friendly' company, Burt's Bees has long positioned its products as 'green consumer' goods; even under new ownership they remain committed to using 'earth-friendly' packaging and ingredients, and they encourage consumers to view their purchases as being environmentally responsible. But by formerly investing company profits in land and by declaring her support for the MWNP, Roxanne Quimby took green consumerism to another level - one where consumer choices and the profits they created were now connected to a politics of identity and landscape control in a place not immediately associated with the production and consumption of the company's products themselves. Whether consumers were always aware of it or not, their decision to buy Burt's Bees in the early 2000s had consequences for more than ingredients and packaging alone. I point to these consequences not to condemn green consumerism as a misguided act or Burt's Bees as a misguided company; indeed, I count myself among those who believe that green consumerism is an important and necessary social practice with the power to benefit nature and society alike. What I would like to suggest, however, is that this 'benefit' to which I and others ascribe is a socially contingent phenomenon - one with material and symbolic consequences that can extend into unexpected and ambiguous terrain. When we shop to save, that is, we can never be quite certain of what it is that we are saving.

I begin the paper by exploring green consumerism's impacts on identity formation, its associations with a given product's commodity chain and its potential to transcend the places most immediately associated with that chain. Next, I explore the MWNP proposal and Burt's Bees former associations with it. I then identify three topics of debate articulated among park supporters and park opponents, each of which highlights green consumerism's role in shaping how people talk about and make sense of landscape and identity in northern Maine. As we shall see, land sales made possible by the sale of Burt's Bees have sparked intense debates between wealthy activists and local officials, between insiders and outsiders, between recreational tourists and working residents. Debates such as these speak to deep-seated struggles to define cultural identity in rural Maine and to define the symbolic meaning of the state's forested interior. Yet they also involve very real struggles to define the structure and management of the physical landscape itself. In this way, they speak to the ongoing importance of studying material as well as symbolic landscapes in cultural geography. ${ }^{2}$

My understanding of these debates has been shaped, in part, by semi-structured interviews with political officials and others connected to Roxanne Quimby and the MWNP. These were conducted during stays in Maine. The insights in the following 
pages, however, are derived primarily from discourse analysis of the massive volume of public opinion published on the MWNP and Quimby's role in it. This includes opinions expressed in formal reports, newspapers and magazine articles, letters to editors of Maine newspapers, online discussion forums, and other printed materials promoting or opposing the park.

\section{Buying green}

As a social practice, consumption creates value and meaning both for consumers and for that which they consume - value and meaning embedded in the larger social and cultural contexts in which consumption takes place. The material goods, images or knowledge that one consumes thereby serve as markers for defining one's values and social position. ${ }^{3}$ This fundamental link between consumption and the production of identity extends to the places associated with consumer goods as well. These include places where consumers shop, places where goods are produced and places represented in marketing imagery. ${ }^{4}$ Many consumers identify the state of Maine, for instance, through its associations with the famous retailer L.L. Bean. Headquartered in the popular tourist destination of Freeport, Maine, this outdoor clothing and equipment company has long advanced an identity for Maine defined by outdoor recreation and a leisurely communion with nature, both of which are enjoyed primarily by white, middle- and upper-class Americans. ${ }^{5}$

Green consumerism, more specifically, offers Western shoppers the opportunity to inform consumer identity with social statements on environmental protection. Green consumerism gained momentum in the United States during the 1980s and 1990s, as shoppers turned in growing numbers to recycled and biodegradable products. Rooted in an environmental critique of consumer culture, green consumerism allows shoppers to distance themselves from the waste and environmental degradation they associate with mass consumerism without having to reject consumerism entirely. ${ }^{6}$ In recent years, consumer analysts have noted a broadening of green consumerism's ethic of 'responsible' shopping beyond its traditional emphasis on the natural environment. Today's concerned shoppers often advocate a broader ethic of 'corporate responsibility' geared towards both environmental and social concerns. Focusing on labour relations, fair trade, human rights and food labelling, many contemporary consumers hope to influence larger networks of environmental and social relations, both at home and abroad. $^{7}$

This broadening of 'responsible' consumption, however, has not eclipsed the environmental core of green consumerism. In fact, by some measures, consumerbased concern for the environment has grown steadily in recent years. This is particularly true among educated middle- and upper-class shoppers, who have increasingly embraced 'earth-friendly' products ranging from food to hybrid cars. In the process, they have added depth to their class status defined by a consumptionbased display of environmental concern merged with a public display of wealth indicated by their ability to purchase what are typically more expensive consumer 
goods. The rising popularity of organic foods among educated and affluent shoppers provides one example of how consumption, environmental responsibility and the construction of class status have coalesced. Many organic shoppers, Julie Guthman has shown, use their attentiveness to food politics to foster a class-based identity defined by environmental concern. ${ }^{8}$ Similar patterns apply to natural personal-care products, the market for which grew dramatically during the 1990s. That which consumers put on their skin and in their bodies, Gill Valentine has argued, can be both a marker of class status and a means for reproducing an environmental ethic. ${ }^{9}$ As consumers turned in growing numbers to 'natural' products like Burt' Bees, then, they quite literally embodied a consumer-based environmental discourse as well as a sense of class distinction.

By focusing on the environmental consequences of consumerism, however, green consumers do more than define class-based identities. In addition, they use monetary exchange to assign value and meaning to nature - a means of defining value, David Harvey suggests, fundamental to Western conceptions of nature. ${ }^{10}$ In this regard, green consumerism becomes a way in which shoppers assign value and meaning to the (often distant) places they associate with a given product's lifecycle. By spending money on earth-friendly products, consumers imagine their actions as having positive material consequences for any or all of the places along a given commodity chain stretching from production and transportation to marketing, use and disposal. ${ }^{11}$ Of course, even the most well-intended consumer's understanding of these places may be vague at best: the daily realities for those who live and work at any point along a commodity chain and the subtle environmental consequences that arise when we make, move and use any product are never entirely visible or comprehensible to shoppers. In particular, Robert Sack reminds us, modern consumer practices relegate 'extraction, production, distribution, waste, and pollution to a hidden backstage'. ${ }^{12}$ Yet at the very least, those who consider - even momentarily - the environmental effects of their consumer choices express an understanding that consumption always carries consequences for places tied to the lifecycles of the products we use. When consumers buy green, then, they assign value and meaning to such places, and they hope their actions will have a positive effect on the ways in which they are managed. We define forests as being of value when we buy recycled paper, for example, and we trust that our decision to do so will translate into the protection of actual trees, even if we will never see the places where those trees are rooted or the people who live therein.

'Trust' as it is used here is an important word, for not only can consumers never know the effects their choices may have on any given place, they also cannot predict or control where their money goes once it is spent. For any capitalist venture to expand, a percentage of its surplus value must be reinvested in the labour and infrastructure necessary to improve upon or to produce a greater quantity of a particular product. As Neil Smith has demonstrated, this process of circulation and expansion is fundamentally dependent on geographical differentiation in levels of development from place to place. This multi-scalar differentiation, Smith argues, perpetuates the condition of 'uneven development' that marks contemporary capitalist societies. ${ }^{13}$ Seen in one way, green consumerism is an attempt to intervene in the circulation of capital and the 
creation of this geographical differentiation in ways that minimize the environmental effects that one's consumer choices may have on a given commodity chain. Consumers might imagine that their choices have beneficial implications for land use in places associated with a commodity's production, transportation, marketing, use and disposal; they might applaud the use of corporate profits to make the pathways of production and consumption more environmentally sustainable and socially equitable.

But what happens when those who control the surplus value generated by the sale of a green commodity circulate capital into places and political agendas unrelated to the production of their particular commodity? What happens when the act of buying green turns out to have implications for places with little or no obvious connections to the products one chooses to buy? What happens when the meanings and values ascribed to a place through the act of green consumerism conflict with the meanings and values that others hold for that place? What if the social and environmental consequences of responsible consumption turn out to be more complicated than we might expect?

That is what happened in northern Maine during the first few years of the twenty-first century, as green consumerism became implicated in a larger struggle over identity and landscape control rooted in conflicts between recreational land uses and resource extraction. Conflicts such as these are not unique to Maine, of course, nor are their potential consequences for the ways in which we use and define our surroundings. ${ }^{14}$ Nevertheless, the ways in which people with an interest in the Maine Woods have understood and talked about those consequences have been shaped, in part, by the unique context of green consumerism. As profits from the sale of Burt's Bees were reinvested in a venture not immediately tied to the product's production and consumption, green consumerism's spatial effects widened dramatically. In this case, consumers spent money on a product known for its responsible use of packaging and ingredients. Some of these consumers would have known about Burt's Bees' support for the MWNP, some would not. Profits from these transactions were then reinvested in an environmental agenda that the company's former owner, Roxanne Quimby, felt would enhance the environmental sustainability of an entire region, regardless of that region's lack of material associations with the production of Burt's Bees products. The full implications of that decision for land use and identity in the Maine Woods may not be realized for years to come.

\section{The Maine Woods and the proposed MWNP}

The Maine Woods (sometimes referred to as the North Maine Woods) is part of the larger Northern Forest bioregion - a zone of spruce, fir, hemlock, maple and beech stretching across the upper reaches of the north-eastern United States. At 10 million acres, the Maine Woods constitutes about half of the state's total area. ${ }^{15}$ Isolation and a harsh winter climate have historically hampered settlement in the region, such that hundreds of surveyed townships in northern Maine remain unsettled and politically unorganized to this day. That does not mean, however, that the region has gone unused. For well over a century, logging crews have cut its timber, transporting logs by 
river and by rail to mill towns for processing into fuel, lumber, pulp and paper. By the early part of the twentieth century, commercial timberland owners such as International Paper and Great Northern had purchased the vast majority of the Maine Woods, drawing the region into their massive pulp and paper empires. Rather than being organized into federally managed national forests, then, the Maine Woods has remained almost entirely privately owned - a pattern that worked reasonably well for timber companies and for generations of working Mainers in towns like Millinocket, Greenville, Rumford and Bangor. ${ }^{16}$

In recent decades, however, Maine's forest-products economy has been on shaky ground. Amidst pressures from rising costs of production, forest diseases, unsustainable harvesting practices, ageing mills and competition from southern and western states, timber companies have scaled back their Maine operations, closing mills, laying off workers and selling their land, often in transactions involving tens or hundreds of thousands of acres at a time. Since the mid-1990s, roughly seven million acres of commercial timberland have changed hands in the state. ${ }^{17}$ Some of this land has moved from one corporate giant to another and has remained available for logging. Other land - particularly lakeshore property - has been sold to vacation home owners, to speculative developers and to distant investment companies whose motives often seem cloudy at best. Landowners want the highest return from their Maine properties, which in a region that is a day's drive from Boston and New York often means selling it for recreational uses rather than for logging. ${ }^{18}$

This instability has thrown the future of land use and identity in northern Maine open for debate, forcing community leaders to explore new ways to generate economic opportunities. ${ }^{19}$ Each major land sale brings a wave of uncertainty and public speculation about how the new owners will use their property. Will they continue to log their land? If so, will they do so in a sustainable way? Will the land be developed for vacation homes? Will it be posted against trespass? Against this uncertain backdrop, citizen groups, environmental organizations and state agencies have been exploring alternate land use models, most of which involve some degree of expansion in the region's tourist economy. ${ }^{20}$ While few can agree on the particulars for the region's future, nearly everyone can agree that the tradition of paternalistic companies providing steady jobs in forests and in mills is a thing of the past.

The Maine Wood National Park has emerged as the largest and most controversial land use option proposed for the region. ${ }^{21}$ First articulated in 1994 by an environmental organization from Concord, Massachusetts, named 'RESTORE: The North Woods', the proposed park would encompass much of northern Maine, including 100 miles of the Appalachian Trail, thousands of lakes and ponds, the headwaters of six major rivers and all of Maine's famed 200000-acre Baxter State Park, which under the RESTORE plan would continue to be managed by the state (Figure 2). For over a decade, RESTORE has maintained that a national park is the best way to secure the long-term environmental and economic wellbeing of northern Maine. Only a national park, RESTORE argues, can protect against irresponsible logging, rampant land sales and uncontrolled recreational development. Under their plan, commercial timber harvesting would continue on land outside the park, but as in all national parks, it would be prohibited 


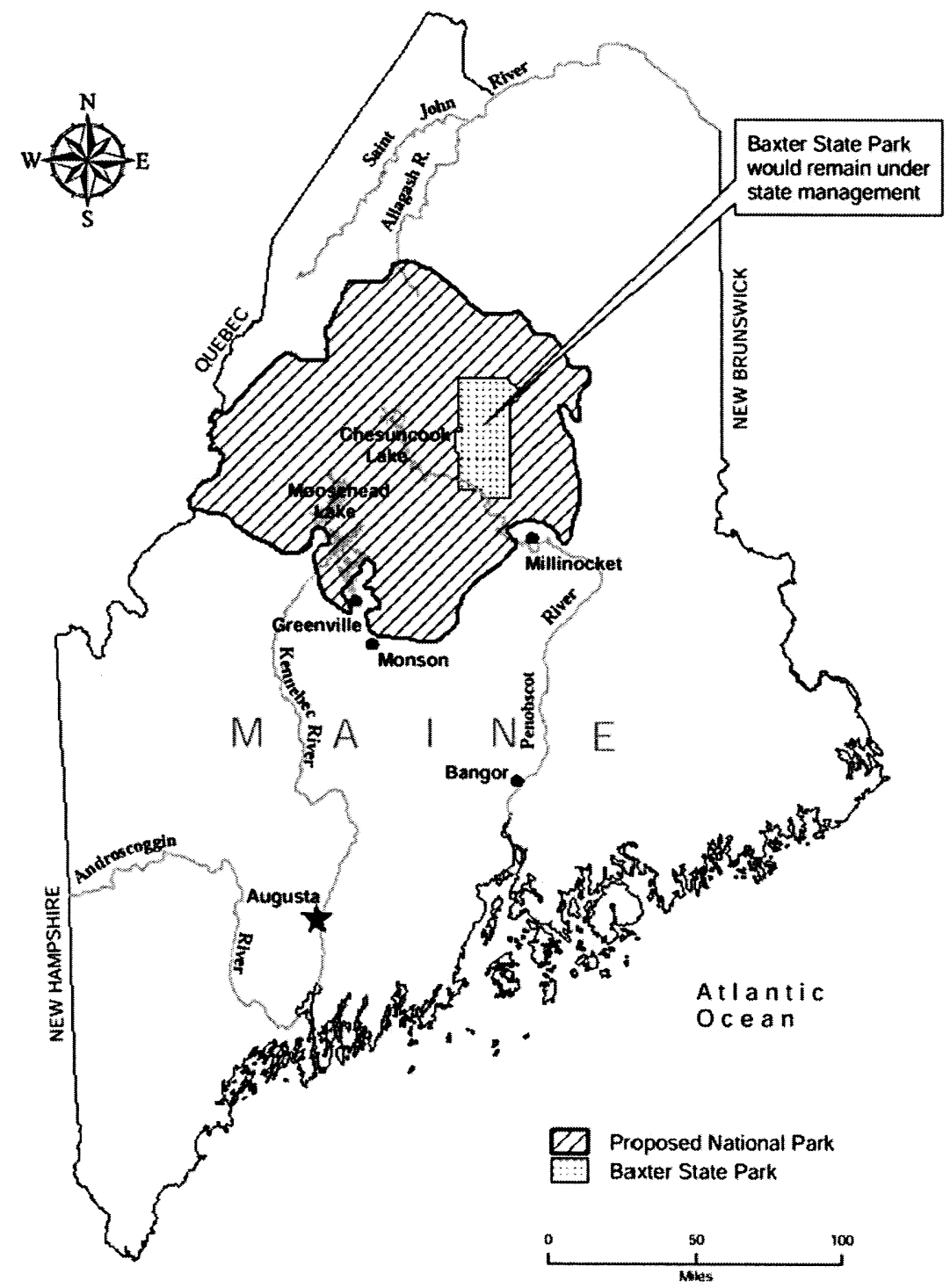

BH

FIGURE 2 The proposed Maine Woods National Park (map by the author)

within the borders of the MWNP. The park would be a carefully managed wilderness landscape, RESTORE contends - one capable of attracting millions of tourists each year, thereby adding jobs, diversity and depth to the region's economy. ${ }^{22}$

In many respects, the MWNP seems an entirely logical proposal for Maine - a state which bills itself as 'Vacationland'. For over a century Maine's natural beauty, rural 


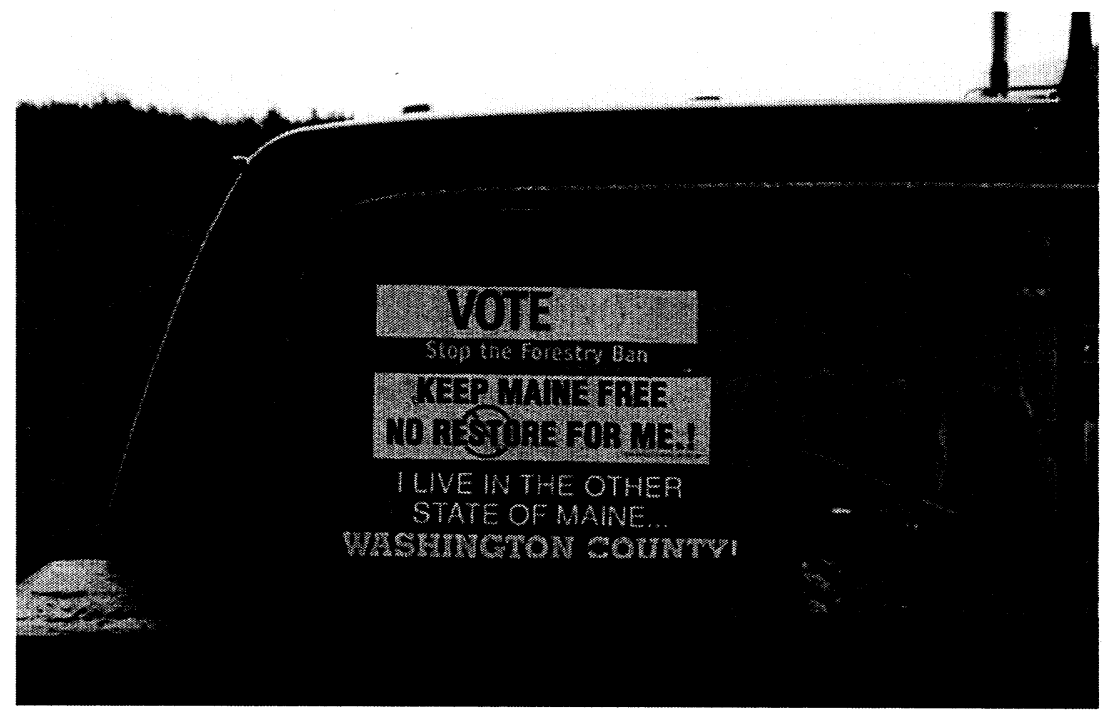

FIGURE 3 Public statements such as these (supporting the forest-products industry, opposing RESTORE and expressing cultural distinctions between different regions of Maine) are not uncommon the further north and east you travel in the state. (Photograph by the author.)

charm and opportunities for outdoor recreation have attracted visitors from the urban north-east and beyond. ${ }^{23}$ More than two million are attracted annually to Acadia National Park on Maine's rocky coastline, and tens of thousands visit Baxter State Park in its forested interior each year. By some measures, then, a new national park would merely build on Maine's tradition of tourism.

Nevertheless, a number of factors have worked consistently against the proposed MWNP. First, opposition to the idea remains widespread in Maine, particularly the further north and east one goes in the state, where many residents feel threatened by the immediacy of the plan and the changes it would bring to their preferred way of life (Figure 3). Although this opposition has never been entirely unified in its concerns or tactics, a range of local and state-based groups do constitute a loosely united front against the proposal. These groups include snowmobile, hunting and fishing clubs, as well as the Maine Woods Coalition, an organization created specifically to oppose the park. Reflecting what Michael Woods has identified as an increasingly vocal 'politics of the rural' in Western society, groups such as these often see themselves as defending a traditional rural 'way of life' in places such as northern Maine. ${ }^{24}$ Second, the NPS has remained uncommitted to the park proposal, as have Maine's recent congressional delegations and state governors. That would need to change for the proposal to move ahead formally. Complicating matters further, the federal government would need to spend millions of dollars to buy private land from willing sellers to create the park; that seems unlikely to happen in this era of wartime spending and a ballooning federal deficit. Third, patterns of landownership and protection in northern Maine have become increasingly complex in recent years, making it more difficult (and some 
would say unnecessary) to create a monolithic national park. Hundreds of thousands of acres in the region have been protected through conservation easements and through direct ownership by the state or by groups such as the Appalachian Mountain Club and the Nature Conservancy. Converting today's complex mosaic of protected land in northern Maine into a federal park would pose a significant legal and logistical challenge.

\section{Burt's Bees and the MWNP}

Although the creation of the MWNP seems unlikely at the moment, the proposal continues to inform public discussion about the region's future. Its persistence in the public mind has been fuelled, in part, by its controversial associations with Roxanne Quimby and Burt's Bees. Quimby was born in Massachusetts and attended college in San Francisco before moving to rural northern Maine in 1975. There, she and her future husband purchased 30 acres of land on which they built and lived in a cabin with no electricity or running water. In the 1980s Quimby, then a struggling single mother, met Burt Shavitz, a local beekeeper raised in New York City. Together they began producing candles, lip balm, hand cream, boot polish and other natural personalcare products from the wax generated by Shavitz's bees. They sold their homemade goods at craft fairs and in natural food stores throughout Maine, before working their way into larger markets in Boston, New York and beyond. By 1993, Burt's Bees had roughly 40 employees and was turning over $\$ 3$ million in sales each year from its headquarters in the small town of Guilford, Maine. A year later, Quimby and Shavitz moved the business to North Carolina, citing factors such as lower taxes, reduced transportation costs and the presence of a more skilled work force. In 1999 Quimby bought out Shavitz, becoming the sole owner of what was by then a 40-million-dollara-year company. Finally, in the fall of 2003, Quimby sold the majority of her interest in Burt's Bees to a New York investment firm for roughly $\$ 175$ million. ${ }^{25}$ Burt's Bees' new owners have distanced themselves from the MWNP, although they remain committed to using 'environmentally friendly' ingredients and packaging.

Quimby first encountered RESTORE and the MWNP proposal in the late 1990s, after which she joined the group's board of directors and began devoting her time, her company's resources and her own personal fortune to the park's creation. By 2001, she was actively purchasing land in the Maine Woods with the intention of donating it some day to the NPS. ${ }^{26}$ Private donations of land for national parks are not unprecedented in American history: during the early decades of the twentieth century, John D. Rockefeller Jr donated substantial amounts of land to help create a number of national parks, including Acadia National Park in Maine. ${ }^{27}$ Likewise, Maine's Baxter State Park owes its existence to the state's former governor, Percival Baxter, who purchased over 200000 acres and donated it to the state. ${ }^{28}$ Working towards a similar goal (and at times being compared in the press to Baxter himself), Quimby purchased large and small tracts of forestland; upon selling Burt's Bees in 2003, she found herself with the 
financial assets to purchase still more. By early 2005 she owned 50,000 acres, making her one of Maine's largest individual landowners.

In many respects, this spirit of environmental activism and the sale of natural personal-care products seemed a logical match. As Burt's Bees' connections to the MWNP became more widely known through outlets ranging from popular magazines to National Public Radio, many consumers would have been pleased to know that their choice for hand cream and lip balm was helping to create a new national park. If they wished, shoppers and retailers could learn more about Burt's Bees' land purchases on the company's website. They could read about the company's commitment to the park on the informational cards which accompanied some of their products (Figure 4). For a time, they could even buy special boxes of greeting cards, the profits from which were used for the 'purchase and preservation of land in the Maine wilderness'. If you were environmentally inclined enough to support green-consumer products, the company's marketing message suggested, you could be assured that your money was going to support an environmental agenda in the state of Maine - a state many Americans already associated favourably with nature, beauty and outdoor life. Burt's Bees' 'conservation acquisitions', the company noted in a public statement, were 'part of an ambitious effort to save the largest surviving area of the great North Woods.... Our children and their children will thank us for having the wisdom and resolve to preserve the heart of the Maine Woods as American's next great National Park. ${ }^{29}$

By reinvesting profits from the sale of Burt's Bees in land, Quimby widened the circle of green consumerism's influence beyond the immediate lifecycle of her company's product itself. Using her financial resources and the power those resources had given her, she intervened in the politics of landscape and identity in the Maine Woods, redefining the value of the region's forested landscape through monetary exchange, and merging its fate with the ethic of green consumerism that guided her company. In this sense, it was not only individual consumers who spent money hoping to save some aspect of the natural environment, it was Roxanne Quimby who, by reinvesting consumer spending in land, spent money that she hoped would save at least some portion of the Maine Woods. What did that mean for how different groups have talked about and understood the future of the Maine Woods? What do their reactions suggest about the power of green consumerism to shape the politics of landscape and identity here and elsewhere?

\section{Debating the MWNP}

When supporters and opponents of the MWNP debate their positions, they typically turn to a number of reoccurring themes. These include: (1) the relationship between economic development and environmental protection; (2) the relative social and political power of outsiders and insiders; and (3) the nature and degree of public recreational access to private forestland. While none of these has evolved into a direct referendum on the act of green consumerism, the topics and tenor of each have been shaped by their associations with Burt's Bees and Roxanne Quimby. Therefore, each of 


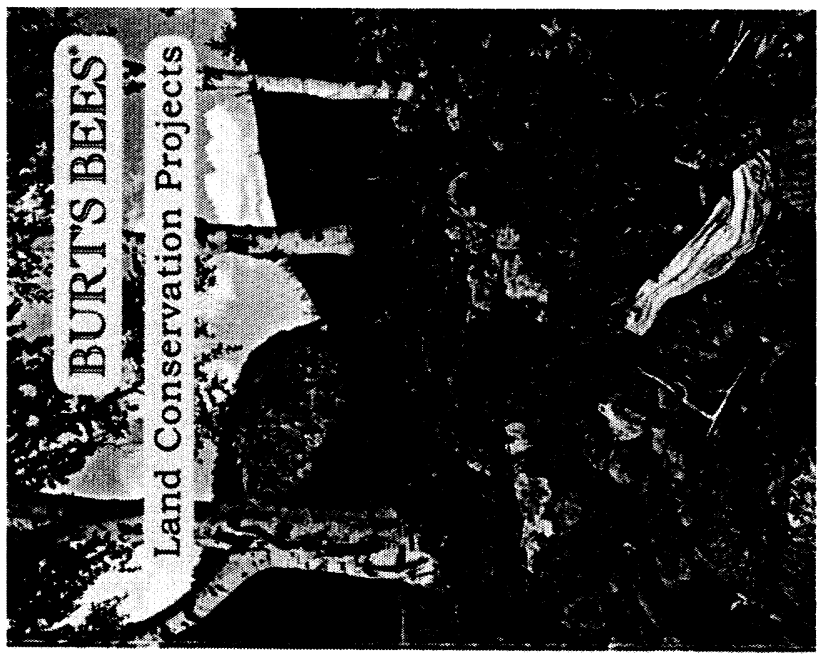

LAAND IN MAINE Ownership Detail

\begin{tabular}{|c|c|c|c|c|}
\hline momen then. & Prokene tente & Fechene Mise & and & minet \\
\hline Bon Whon Preserve & nqual 4200 & 867008 & 247 & 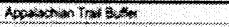 \\
\hline Bulte Presene & nyst 4 200 & st 6000 & 5869 & Natur conetres 84 the \\
\hline Lithe Ontroos Pon Pletere & Wy $2,26 \%$ & vots 00 & 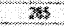 & 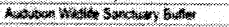 \\
\hline Whoc fresorit & 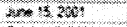 & SS6 OWO & $n$ & 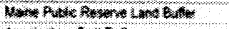 \\
\hline 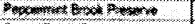 & onoos 3 , 20t & 54.000 & 26 & 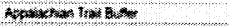 \\
\hline Seress fons present & 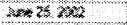 & $\$ 24000$ & $50 \%$ & 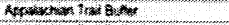 \\
\hline 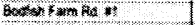 & $x+17002$ & $520 \%$ & 4 & 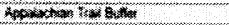 \\
\hline 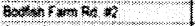 & Wr 3002 & $\$ 24,08$ & 41 & Gowaches Tril arter \\
\hline stano hogers & 4) 320 & s34 60 & $9 ?$ & 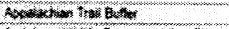 \\
\hline So Ononwosed Frat & Sectenter to $20 \mathrm{~s}$ & 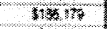 & 6 & 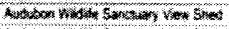 \\
\hline 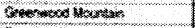 & Setender 3.200 & $\$ 4000$ & 35 & 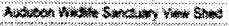 \\
\hline Dompin $x^{\prime}$ & 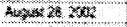 & 1000 & 6 & Goworon ind elles \\
\hline Whexwer cost. & sops 2.006 & $\mathbf{5 0 0 0 0 0 0}$ & 41 & Sereicectum lav Buth \\
\hline Brsonsm fand & Decenow tt $\mathrm{wh}$ & $m \infty$ & si? & 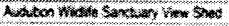 \\
\hline 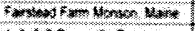 & Cosseree $2 \mathrm{~kg}$ & sivts: & 24 & Frocent und Tines otems \\
\hline 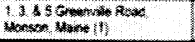 & mowy to 2009 & strsp & 2 & 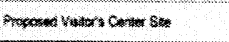 \\
\hline & rente: & $97,10,234$ & 15,024 & \\
\hline
\end{tabular}

Visit our website at WWW. burtsbees. COM to find out how you can help.

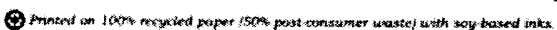


these three themes gives us a chance to consider green consumerism's potential to influence land use and identity on a scale wider than consumers might expect.

\section{Economy and environment}

Debates about the MWNP are often framed according to the relationship between environmental protection and economic development. Is it best to enhance the local economy by increasing the scale of its nature-based tourist economy, some ask, or is it best to continue using the regional forest for timber production? Questions such as these speak to broader debates about the relative merits of production-based (logging) and consumption-based (tourist) economies - debates that are, of course, not unique to northern Maine. Other rural communities throughout the United States struggle to reconcile the interests of tourists, recreational developers and new amenity-seeking residents with those of working residents, whose livelihoods and identities are often linked to a resource-extractive economy. ${ }^{30}$ Yet debates about environmental protection and consumptive landscapes carry a unique twist in northern Maine, where they have been interwoven with the environmentalist act of green consumption itself. Using the power of a fortune generated by green consumerism, Quimby sought to transform the future of the region into an economy that many feel is geared too much towards consumption and not enough towards production.

Those who support the proposed MWNP view environmental protection and economic development as complementary goals. Northern Maine's forests are threatened by many different problems, including clearcutting, pesticide usage, road construction and uncontrolled recreational development. The MWNP, park supporters argue, would solve these problems, restoring and protecting the region's forests while at the same time creating new economic opportunities capable of 'revitalizing, diversifying, and stabilizing the troubled economy of the region'. ${ }^{31}$ By this logic, the park's borders would define a new, environmentally sustainable landscape of consumption, born of what some consider a failed landscape of production. Here visitors would passively consume scenic beauty rather than actively consuming the trees themselves. Outside the park's borders, moreover, visitors would also consume very real goods and services. Towns such as Greenville and Millinocket would serve as 'gateway communities' for the park, where hundreds of thousands of new visitors each year could purchase food, entertainment, lodging and fuel.

Most area residents feel that northern Maine needs new economic opportunities, but most also feel that a national park is not the best way to achieve them. There are two reasons for this. First, traditional patterns of land use and traditional conceptions of cultural identity in the region are tied closely to the maintenance of what residents call a 'working forest' - a privately owned landscape upon which jobs in logging and millwork have long been based. For many, the concept of a working forest has become a potent symbol of regional heritage around which park opponents can rally. ${ }^{32}$ Any plan that disallows timber harvesting on 3.2 million acres of forestland thus seems to undermine completely the region's traditional economy and traditional way of life. And 
for some, that borders on insult. As stated by Gene Conlogue, the outspoken town manager of Millinocket and co-founder of the opposition group, the Maine Woods Coalition, 'We're not interested in trading jobs that pay $\$ 20$ an hour for trinket-selling jobs at $\$ 6$ an hour. ${ }^{33}$ Second, residents will quickly point out that northern Maine already has a large wilderness park (Baxter State Park) where commercial logging is prohibited, and that in fact the region's working forest is already home to a naturebased tourist economy rather than to logging alone. Towns like Greenville and Millinocket already act as gateway communities for the Maine Woods, serving tens of thousands of visitors each year. Increasing the scale of their tourist economies at the expense of other industries seems like a bad decision, some residents argue, particularly when other gateway communities to existing national parks are notorious for problems such as visual blight, sprawling development and high taxes. ${ }^{34}$

Upon her entry into these debates, Roxanne Quimby quickly became associated with the creation of a consumer-oriented tourist landscape geared more towards protected nature than towards resource extraction. For some observers, using profits from the sale of a green-consumer product to help create a national park seemed like a logical and reasonable thing for a company like Burt's Bees to do. 'Our [company's] inspiration was Mother Nature,' Quimby told one industry observer. 'We wanted to create products that reflected the beautiful smells, colors, and sights of the rural landscape, which we believed to be healing and nurturing as well as beautiful. ${ }^{35}$ This sense of nature-asinspiration is a common theme among manufactures of green-consumer goods, for whom purity, natural goodness and a discourse of environmental protection are embedded in and perpetuated by their products. By extension, then, it seemed in keeping with the company's ethic of 'healing and nurturing' to reinvest a portion of its profits into land purchases designed to help create the MWNP. 'I can think of no better thing to do with Burt's Bees profits', Quimby explained, 'than to return them to the earth. ${ }^{36}$

Many consumers who knew of Burt's Bees' formal support for the MWNP would have also viewed this blend of product and place as a logical match. Among some Americans, the state of Maine carries strong associations with natural beauty, with environmental awareness and even with green-consumer goods. Shoppers associate other socially responsible companies with Maine, for instance, including 'Tom's of Maine', maker of a popular line of natural toothpaste and well-known advocate of environmentalism and social justice. ${ }^{37}$ In earlier years, Burt's Bees also reproduced Maine's nature-based and environmental reputations; and although now headquartered in North Carolina, company profiles continue to emphasize its Maine roots, linking the identities of product and place. ${ }^{38}$ Links such as these can have tremendous power. As Mona Domosh has shown in her study of marketing, companies may use favourable notions of 'purity' to advance cultural or political agendas. By emphasizing the literal and cultural purity of its foods, she suggests, the Heinz Corporation became an agent of early twentieth-century American imperialism. ${ }^{39}$ In a similar way, Burt's Bees' associations with purity, coupled with Maine's associations with natural beauty, suggested to consumers a seemingly inevitable and entirely favourable set of connections between company, place and national park. 


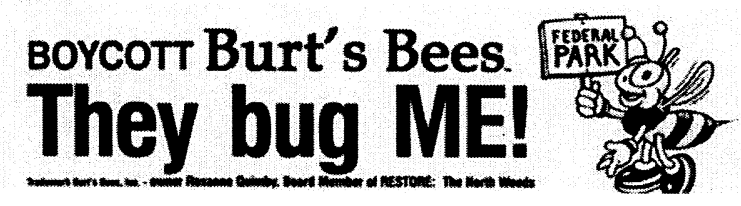

FIGURE 5 Bumper stickers like this reveal the direct and unfavourable connections that many area residents made between Burt's Bees and the MWNP. (Author's collection.)

Many area residents also made connections between product and place like these, yet they have tended to approach them with a mix of suspicion for Quimby's motives and fear for the power of her financial resources. Naturally, not everyone in northern Maine and not everyone who opposes the MWNP disapprove of Burt's Bees as a company, nor do they object to the concepts of green consumerism or environmentalism with which that company is associated. But a great many responded to news of Quimby's initial land purchases in 2001 by calling for a boycott of Burt's Bees and by discouraging the sale of the company's products in local stores (Figure 5). A great many continue to have no interest in supporting the company today, even though its new owners no longer back the MWNP. At the root of their opposition lie persistent questions about the relative weight of consumptive and productive economies and the relative value of prohibiting logging in what have long been working forests. Put another way, their opposition is rooted in persistent questions about the wisdom of embracing an expanded consumer-based tourist economy enhanced, in this case, by an economy of green consumerism.

Residents in places like Monson, Maine, have been grappling with such questions in very personal ways, particularly in light of Quimby's substantial economic power. By 2003, Quimby was envisioning Monson as a possible home for a national park visitors' centre. To help make that vision come true, she purchased three homes in Monson's village centre, gave the homes away to anyone who would remove them from the land for scrap, and then set about planning a visitors' centre, which she hoped would become the nucleus of an entirely new kind of Monson. As she told one journalist, 'I think it could be a fascinating art and outdoor recreation town. ${ }^{40}$ Some in Monson agreed, seeing a future visitors' centre as a potential catalyst for an expanded tourist economy. But others remained suspicious of any model for the town's future based more on consumption than on production. As argued by John Wentworth, president of a furniture factory in Monson's village centre, Quimby's vision for an 'art and outdoor recreation town' represented a 'false economy' based not on 'value-added' business like his own but on small-scale tourist operations. There simply can never be enough hikers in the Maine Woods, he argued, to generate the number of high-paying jobs that a revitalized forest-products industry could. ${ }^{41}$ When Quimby's visitors' centre stalled, and when Quimby's initial interest in the town seemed to fade, residents in Monson were left with a gaping hole in the centre of their village and continued uncertainty about the future of their town. 


\section{Outsiders and insiders}

In addition to issues of production and consumption, debates about the MWNP often focus on the relative power of insiders and outsiders to control the future of land use and identity in northern Maine. Such debates revolve around fundamental questions about cultural values and landscape control. All landscapes may be used to reproduce and naturalize given cultural values, thereby reinforcing the power of some social groups over others. ${ }^{42}$ As with any landscape, then, the central question facing northern Maine is not merely bow the regional landscape will be structured and managed, but whose values and whose power will it serve. Roxanne Quimby's decision to reinvest profits from her company in land in northern Maine implicated the act and ethic of green consumerism in questions such as these. Quimby's involvement and her associations with green consumerism came to be seen by some as an imposition of new cultural values associated with environmental activism and with people from outside the region. In this way, green consumerism became tied to ongoing struggles to define both the meaning and management strategy of the region's forested landscape.

For many who support the MWNP, the Maine Woods is a nationally significant natural landscape - one which should be protected at the federal level by the NPS for the benefit of visitors from throughout the world. Some area residents, however, view this as a justification for a power grab by outside interests intent on rescripting the region's future according to cultural values that many residents feel are not their own. In part, this concern centres on questions of governance. Echoing sentiments associated with the 'Wise Use' movement in the American West, many in northern Maine hold deep-seated beliefs in the sanctity of private property, the importance of local control and the danger of federal oversight of local land use. ${ }^{43}$ In addition, concerns about outside influence are rooted in perceived social and cultural differences between Maine residents and what many refer to as people 'from away'. Maine residents are often viewed (by themselves and by others) as being culturally distinct, particularly in light of the state's long history of geographical and economic isolation. While this isolation is a thing of the past in nearly all parts of Maine, many residents perpetuate their sense of distinction proudly by emphasizing fundamental differences between themselves and all those who are from away. The concept of being from away perpetuates unwritten cultural and social rules about who can and cannot claim insider status in the state: some argue that new residents do not become 'true' Mainers until their families have lived in the state for three or more generations; some white Mainers resist the inclusion of non-whites within the boundaries of the state's cultural identity; and by no means can tourists claim to be anything other than outsiders. Divisions emerge within the state as well: residents of northern Maine and the state's far eastern coastline often posit themselves as being 'true' Mainers, distancing themselves from residents in the southern part of the state with whom they often differ on a range of political, economic and social issues. $^{44}$ 
The MWNP proposal has sharpened political, social and cultural divisions between insiders and outsiders in Maine. RESTORE's Massachusetts roots, for instance, stigmatized the organization from the start: 'What right do they [RESTORE] have to come up here and tell us how to live?' one resident of Millinocket asked a journalist from the Boston Globe. 'The arrogance. ${ }^{45}$ Another commentator maintained that 'real, live Mainers from all sorts of far-flung places have rejected the group's proposal as nonnative ranting and raving, and a major violation of the Maine Law of Being From Away'. ${ }^{46}$ Roxanne Quimby's land purchases only added to this sense of persecution at the hands of people from away. Quimby was born in Massachusetts, some quickly pointed out, not in Maine. She is a self-professed 'tree hugger', an outspoken vegetarian in a region with a strong hunting tradition, and a highly successful woman asserting her influence in a region where the masculine overtones of a logging economy remain strong. ${ }^{47}$ Worse still, she helped to establish an advocacy group in 2003 named 'Americans for a Maine Woods National Park'. Designed to put the park issue 'on the national agenda', the group's 100-member roster consisted of high-profile intellectuals and environmental activists, including Julia Butterfly Hill, Bill McKibben and Stewart Udall, as well as an assortment of Hollywood celebrities, including Anthony Hopkins, Meryl Streep and the late Christopher Reeve. ${ }^{48}$ Area residents were quick to voice their opposition to the group and to the idea of 'famous' outsiders speaking on their behalf. Hundreds gathered in public protest in Millinocket, for instance, where they held a 'mock film festival' described by one participant as 'Maine people fighting for what Maine people want'. 49

Opposition such as this suggested the presence of perceived social and cultural differences between local park opponents and those who, in one commentator's words, "conspire to turn much of the state into a national park/playground for the idle rich'. ${ }^{50}$ For some, Burt's Bees and the message of environmental protection they were selling through their product line were clear embodiments of this distinction. As one opponent argued in a 2005 online discussion forum:

[Burt's Bees is] [a]nother business with an overpaid CEO who thinks she knows what is best for Maine along with her Hollywood backers .... How many people in Maine know nothing of what this woman is doing? Headline: 'Out of State Resident Milionaire [sic] buying up the state of Maine and cotrolling $[s i c]$ what you do in your backyard' .... I could go on and on about Roxanne. My last words: BOYCOTT BURT'S BEES. $^{51}$

From this viewpoint, boycotts and resistance to Roxanne Quimby and Burt's Bees reflect links made by some between the message of green consumerism and the future of land use in the region. What Quimby's land purchases symbolized was a marriage of environmental activism and millions of dollars of disposable income - a marriage made possible by the sale of an environmentally inclined product to environmentally inclined shoppers whose cultural values seemed out of touch with local sentiment. One possible outcome, some have worried, was the triumph of outsider interests over a 'true' Maine way of life. Commenting on Quimby's perceived agenda, one observer branded her and her supporters agents of 'government coercion' and harbingers of a 'feudalist/ socialist system controlled by an eco-bureaucracy': 
No one should think that Roxanne Quimby and her cohorts are simply buying an unusually large amount of land in Maine - this is much more than an issue of who owns some of the land or whether it will be 'preserved.' It is also much more than preservationism harming the local economy and locking up some land against traditional uses such as hunting, logging, ATVs and snowmobiles, although that is part of the environmentalists' national agenda.

Environmentalism is an ideological political movement driven by enormous funding. They are after nothing less than a cultural and political power grab for sweeping control across rural Maine. They must eliminate private property and the private economy if they are to attain their goals for 'biodiversity-based' economics and massive wilderness restrictions to destroy civilized life and 'restore' the 'primeval' across tens of millions of acres. ${ }^{52}$

Whether the 'enormous funding' that this critic fears was generated through public money, private donations or the sale of green consumer goods, the values of those who wielded it seemed in no way representative of what he perceived to be local opinion. Yet arguments like these that posit Quimby and her outsider-supporters against a seemingly unified bloc of local opinion miss a critical point. As park supporters often point out, the Maine Woods has for generations been owned and managed by individuals and corporations 'from away'. As RESTORE argues, residents should not assume that corporate landowners like the Seattle-based timber and real-estate giant Plum Creek (which owns nearly a million acres in Maine) have their true interests at heart. ${ }^{53}$ Increasingly, many area residents appear inclined to agree. Local opposition is mounting, for instance, against a massive proposal from Plum Creek to build two resorts, nearly 1000 home lots, a golf course, and other recreational developments on 14000 acres of land near Greenville. Commercial timberland owners like Plum Creek are beginning to experience the kind of pressure and scrutiny that Quimby and Burt's Bees experienced between 2001 and 2003 - even from former political allies in area towns. $^{54}$

Nevertheless, many still consider land owned by companies like Plum Creek a more likely source for jobs and economic growth than land owned by Roxanne Quimby. And in this sense, Quimby, Burt's Bees and those who supported them with their consumer dollars remain outsiders, with values that are portrayed as being out of synch with those of area residents. When Quimby invested profits from her company on behalf of the MWNP, she did more than implicate herself and her company in regional politics: she implicated the cultural values of those who purchased their products in an intense struggle to control the future of northern Maine. The consumer who purchased a tube of Burt's Bees lip balm therefore became an instant outsider in a politics of identity and landscape control that probably went well beyond what they would have expected.

\section{Private property and public access}

A final set of debates about the MWNP and Burt's Bees's place within it focus on issues of access and questions about class-based recreational preferences. Maine residents 
have a long history of accepting and expecting open public access to private land in the Maine Woods. In particular, large timber companies traditionally offered recreational access to their land as a way to appease local workers and to give a modest return to the State, whose property-tax code favours commercial timberland owners. ${ }^{55}$ Consequently, generations of Maine residents have grown accustomed to using private land in the Maine Woods for hunting, fishing and snowmobiling. Additionally, thousands of families hold leases to private land entitling them to maintain modest vacation cottages, or 'camps'. Those who run local hunting and fishing lodges have also come to depend on open access to private forestland for the success of their businesses. Although users are now required to pay a modest fee in some areas of the Maine Woods, visitors still enjoy a very liberal system of access - one that many see as central to the region's economy and cultural identity.

Yet with each new land sale in the Maine Woods, the future of this system becomes far less certain than it once appeared to be. Some new landowners - vacation home owners, investment companies and developers among them - are less inclined to honour informal traditions regarding access. A growing tendency to post private land against trespass is therefore causing many to worry about losing access to favoured hunting grounds, or even to lose their family's camp lease.

Supporters and opponents of the MWNP both agree that the future of recreational access in the Maine Woods remains uncertain at best. Where they differ is on how to address this problem. Park supporters view federal ownership and management as the best way to protect access rights in northern Maine. National parks belong to all Americans, they reason, and anyone can enter and use them. ${ }^{56}$ While this is true, restrictions do exist governing the kinds of activity that visitors can pursue within park borders. Permissible activities include things such as fishing, hiking, bicycling and auto touring, and - although there are exceptions - prohibited activities typically include hunting, trapping, snowmobiling, farming, mining and logging. Thus, like all tourist landscapes, national parks create within their borders a sense of distinction - leading even to exclusion - based on their structure, management, and group-based associations. ${ }^{57}$ MWNP opponents see restrictions on the kinds of recreational activity allowed in national parks as an infringement on their assumed right of access in Maine Woods, as an affront to their cultural identity, and as a threat to the region's existing tourist economy, so much of which is geared towards hunting and snowmobiling. The possibility that such activities might some day be prohibited across 3.2 million acres of forestland has caused many sportspeople, business owners and outdoor clubs to oppose the MWNP on issues of access alone. ${ }^{58}$

For some park opponents, Roxanne Quimby's decisions about land management became something of a barometer for the future of recreational access in the Maine Woods. Quimby's land, in this sense, embodied more than cultural values 'from away'. Rather, it embodied the emerging power of particular class-based perspectives on recreational activity and recreational management. Quimby and her supporters, some feared, would impose upon the region a largely urban, middle- and upper-class set of conceptions about outdoor recreation - one based on preferences for activities such as hiking and cross-country skiing rather than hunting and snowmobiling, and one 
whose power has been enhanced in the region thanks to the act of green consumerism. Of course, not all local residents hunt and ride snowmobiles, and not all eschew hiking. And of course, many will point out that the regional tourist economy depends on nonhunters as well as non-motorized recreation. But many who oppose the MWNP continue to fear that well-to-do outsiders whose recreational tastes favour hiking, whose political tastes favour a national park and whose consumer tastes favour green consumer products are making symbolic and physical inroads in the region because of Quimby's decision to purchase land in the Maine Woods.

Fears such as these escalated in 2003, when Quimby purchased an entire unorganized township (24000 acres) named T5R8 from the Canadian timber and investment firm J.D. Irving, Limited. Initial rumours of Quimby's purchase set off a wave of angry speculation that she might intend to close her property to public use. Ten families held camp leases in T5R8, the township was popular among hunters and snowmobilers, and a number of recreational businesses depended on open and free access to its forests. ${ }^{59}$ As soon as news of Quimby's purchase was made official in November 2003, she became the target of intense criticism. ${ }^{60}$ As a guest speaker at a December meeting of the Industrial Forestry Forum in Brewer, Maine, for instance, Quimby found herself confronted by protesters and by a sceptical audience of industry leaders. What she wanted, she told her audience, was to leave her land alone, to let it grow wild. That meant an end to logging, a likely end to camp leases and perhaps an end to hunting and snowmobiling. ${ }^{61}$

For Quimby's detractors, her initial plans for T5R8 would have come as no great surprise. With a largely critical regional press highlighting her vegetarian lifestyle, her dislike for motorsports and her ties to RESTORE, T5R8 seemed to foreshadow an end to open access and a takeover by a new class of recreational users. 'While Quimby may allow the occasional environmentally conscious hiker to tiptoe across her forested estate,' one critic argued, 'she's made it clear most of the activity that constitutes northern Maine's feeble economy won't be permitted. ${ }^{62}$ This sense of exclusion and disenfranchisement at the hands of the 'environmentally conscious hiker' is what makes Quimby's land purchases seem so objectionable to some. Even though Quimby repeatedly emphasized her intention to give her land to the American public, many still see her actions as serving a select class whose tastes are not representative of local tradition. Indeed, whether or not Quimby's 50000 acres ever become part of a national park is almost beside the point. Her stated opposition to hunting and motorized recreation created a lasting impression among many that they will ultimately be excluded, first on her land and then perhaps elsewhere in the Maine Woods as well.

\section{Conclusion}

Although Roxanne Quimby occasionally reaffirms her support for the MWNP in the regional press, she resigned from her position on the board of directors at RESTORE in 2003, and she has since distanced herself publicly from the group. Instead, she 
now manages her land and pursues other conservation initiatives through her Mainebased non-profit organization, Elliotsville Plantation, also known as 'Keep ME Beautiful'. ${ }^{63}$ Park opponents have not stopped vilifying Quimby and Burt's Bees, however, nor have they failed to point out her continuing influence over the future of land use in the Maine Woods. That influence was made possible by countless consumers who purchased earth-friendly personal care products and by Quimby's initial decision to reinvest profits from her former company in support of the MWNP. In this way, the act and ethic of green consumerism became implicated symbolically as well as materially - in an ongoing politics of identity and landscape control in northern Maine. Green consumerism, like all forms of consumption, therefore has the potential to do more than generate value and meaning alone: it has the potential to create very real consequences for how we use and manage our surroundings.

That fact should remind us that even the most well-intended consumer choices harbour complex social and environmental consequences. Responsible consumerism is a laudable agenda, yet it remains, fundamentally, a form of consumption. As such, it is continually implicated in larger networks of social and environmental relations that invariably spell problems for one group or another. Consumption, the anthropologist Richard Wilk has argued, forces societies to confront a host of difficult issues, including 'problems of distributive justice, balancing the goals and desires of people, the ownership and control of objects and resources, and the problem that consumption can destroy or deplete common resources. Because each person's consumption affects others, the issue of the common good can never be escaped. ${ }^{, 64}$ Understanding and taking responsibility for the geographical consequences of consumerism, Robert Sack has also argued, is central to our ability to act as socially moral agents. ${ }^{65}$ And while Sack suggests that modern societies fail collectively at that charge, green consumerism does represent a broad-based attempt among consumers to take Wilk's 'common good' into account as they walk the aisles in local stores. When shoppers buy green products, they express a desire to intervene in a positive way in the pathways of production and consumption associated with the lifecycle of a given product.

As the story of the Maine Woods suggests, however, it is not so easy to define the starting and ending point of that lifecycle, nor is it right to assume that the consequences of our green-consumer choices are limited to places tied directly to a particular product. Just as consumers can never understand fully the complexity of a given commodity chain, so too can we never control the pathways our dollars take once they are spent. Shopping for products made with earth-friendly ingredients or recycled components is no exception, for as with any consumer practice, shopping to save is never an entirely innocent act. The money we spend when we buy green products does not have to flow back into the lifecycle of a particular product. Rather, it can flow outward towards any number of places and political causes, expanding green consumerism's effects into what may be unexpected or even ambiguous terrain. 


\section{Notes}

1 The proposal is also referred to as the 'Maine Woods National Park and Preserve'. See note 58.

2 T. Cresswell, 'Landscape and the obliteration of practice', in K. Anderson, M. Domosh, S. Pile and N. Thrift, eds, Handbook of cultural geography (London, Sage, 2003), pp. 269-81; D. Mitchell, 'Cultural landscapes: just landscapes or landscapes of justice?', Progress in buman geography 27 (2003), pp. 787-96; D. Mercer, 'Future histories of Hanford: the material and semiotic production of a landscape', Cultural geographies 9 (2002), pp. 35-67.

3 A. Appadurai, 'Introduction: commodities and the politics of value', in A. Appadurai, ed., The social life of things: commodities in cultural perspective (Cambridge, Cambridge University Press, 1986), pp. 3-63; P. Bourdieu, Distinction: a social critique of the judgement of taste, trans. R. Nice (Cambridge, MA, Harvard University Press, 1984), esp. pp. 226-317; T. Princen, M. Maniates and K. Conca, eds, Confronting consumption (Cambridge, MA, MIT Press, 2002); S. Zukin, Point of purchase: how shopping changed American culture (London, Routledge, 2004); V. deGrazia, ed., The sex of things: gender and consumption in bistorical perspective (Berkeley, University of California Press, 1996).

${ }^{4}$ For further discussion, see J. Goss, 'Geography of consumption I', Progress in buman geography 28 (2004), pp. 369-80; J. Kneale and C. Dwyer, 'Consumption', in J.S. Duncan, N.C. Johnson and R.H. Schein, eds, A companion to cultural geography (Malden, MA, Blackwell, 2004), pp. 298-315; S.M. Schnell and J.F. Reese, 'Microbreweries as tools of local identity', Journal of cultural geography 21 (fall/winter 2003), pp. 45-69; N. Gregson, L. Crewe and $\mathrm{K}$. Brooks, 'Shopping, space, and practice', Environment and planning D: society and space 20 (2002), pp. 597-617; P. Williams, P. Hubbard, D. Clark and N. Berkeley, 'Consumption, exclusion, and emotion: the social geographies of shopping', Social and cultural geography 2 (2001), pp. 204-20; D. Miller, P. Jackson, N. Thrift, B. Holbrook and M. Rowlands, Shopping, place and identity (London, Routledge, 1998); P. Jackson and N. Thrift, 'Geographies of consumption', in D. Miller, ed., Acknowledging consumption: a review of new studies (London, Routledge, 1995), pp. 204-37; R.D. Sack, Place, modernity, and the consumer's world: a relational framework for geographical analysis (Baltimore, Johns Hopkins University Press, 1992); J. Price, 'Looking for nature at the mall: a field guide to the Nature Company', in W. Cronon, ed., Uncommon ground: retbinking the buman place in nature (New York, Norton, 1996), pp. 186-203.

5 R.W. Judd and C.S. Beach, Natural states: the environmental imagination in Maine, Oregon, and the nation (Washington, DC, Resources for the Future, 2003), pp. 215-17. For a related discussion about consumerism and place identity in New England, see C.C. Hinrichs, 'Consuming images: making and marketing Vermont as distinctive rural place', in E.M. DuPuis and P. Vandergeest, eds, Creating the countryside: the politics of rural and environmental discourse (Philadelphia, Temple University Press, 1996), pp. 259-78.

${ }^{6}$ J. Elkington, J. Hailes and J. Makower, The green consumer (New York, Penguin, 1990).

7 D. MacKenzie, 'You can still shop to save the world', New Statesman (10 Jan. 2000), pp. xiixiii. Also see M.J. Cohen and J. Murphy, eds, Exploring sustainable consumption: environmental policy and the social sciences (New York, Pergamon, 2001).

8 J. Guthman, 'Fast food/organic food: reflexive tastes and the making of "yuppie chow"', Social and cultural geography 4 (2003), pp. 45-58.

9 G. Valentine, 'A corporeal geography of consumption', Environment and planning D: society and space 17 (1999), pp. 329-51.

${ }^{10}$ D. Harvey, Justice, nature, and the geography of difference (Malden, MA, Blackwell, 1996), pp. $150-75$. 
11 For discussions and critiques of commodity chains, see E. Hartwick, 'Geographies of consumption: a commodity-chain approach', Environment and planning D: society and space 16 (1998), pp. 423-37; E. Hartwick, 'Towards a geographical politics of consumption', Environment and planning A 32 (2000), pp. 1177-92; D. Leslie and S. Reimer, 'Spatializing commodity chains', Progress in buman geography 23 (1999), pp. 401-20; P. Jackson, 'Commercial cultures: transcending the cultural and the economic', Progress in buman geography 26 (2002), pp. 3-18.

12 Sack, Place, modernity, and the consumer's world, p. 104. Also see W. Cronon, Nature's metropolis: Chicago and the Great West (New York, Norton, 1991).

${ }^{13} \mathrm{~N}$. Smith, Uneven development: nature, capital and the production of space, 2nd edn (Oxford, Blackwell, 1990).

${ }^{14}$ Recent American-based case studies linking the cultural politics of identity to land use conflicts such as that explored in this study include: A.K. Wondrak, "Seen any wildlife?" Community conflict and a struggle for the soul of Estes Park, Colorado', Cultural geographies 9 (2002), pp. 68-94; J. Kosek, 'Deep roots and long shadows: the cultural politics of memory and longing in northern New Mexico', Environment and planning D: society and space 22 (2004), pp. 32954.

15 D. Dobbs and R. Ober, The northern forest (White River Junction, VT, Chelsea Green, 1995); C.M. Klyza and S.C. Trombulak, eds, The future of the northern forest (Hanover, NH. University Press of New England, 1994).

${ }^{16}$ R.W. Judd, E.A. Churchill and J.W. Eastman, eds, Maine: the Pine Tree State from prebistory to the present (Orono, University of Maine Press, 1995); N. Rolde, The interrupted forest: a bistory of Maine's wildlands (Gardiner, ME, Tilbury House, 2001).

17 Klyza and Trombulak, The future of the northern forest ; L.C. Irland, The northeast's changing forest (Petersham, MA, Harvard University Press for the Harvard Forest, 1999); L.C. Irland, Northeastern paper mill towns: economic trends and economic development responses (Orono, Maine Agricultural and Forest Experiment Station, University of Maine, Oct. 2001); 'The biggest tree sale of all', Economist 353 (6 Nov. 1999), pp. 28-29; J.H. Cushman, Jr, 'For sale: 5\% of Maine, plenty of trees', New York Times (11 Aug. 1998).

18 L.C. Irland, Land, timber, and recreation in Maine's Nortbwoods (Orono, Maine Agricultural and Forest Experiment Station, University of Maine, Mar. 1996); S.C. Harper, L.L. Falk and E.W. Rankin, Northern forest lands study of New England and New York (Rutland, VT, United States Department of Agriculture, Forest Service, 1990).

19 J. Simko, Greenville at the crossroads: the dire need to grow our population and to enrich our community, an unsolicited analysis and proposal prepared by town manager, John Simko, 2002 (unpublished report mailed to the author, spring 2005).

20 C.J. Reilly, C.E. Morris, Nature-based and cultural-beritage tourism in Piscataquis County (Orono, ME, Margaret Chase Smith Center for Public Policy, 2004).

${ }^{21}$ For a detailed look at the park proposal, see B. Harrison, 'The Maine Woods National Park: landscape, regional identity, and the promise of New England geography', Studies in New England geography 19 (Jan. 2005).

22 Proposed Maine Woods National Park and Preserve (n.d., 16-page informational tabloid published by RESTORE: The North Woods; author's collection). Also see M.J. Kellett and J.A. St. Pierre, Gateway to a healthy economy: the proposed Maine Woods National Park and Preserve and the future of the Moosehead region of Maine (Concord, MA, RESTORE: The North Woods, 1996).

${ }^{23}$ G.H. Lewis, 'The Maine that never was: the construction of popular myth in regional culture', Journal of American culture 16 (summer 1993), pp. 91-99; S.J. Hornsby, 'The Gilded Age and 
the making of Bar Harbor', Geographical review 83 (Oct. 1993), pp. 455-68; D. Brown, Inventing New England: regional tourism in the nineteenth century (Washington, DC, Smithsonian Institution Press, 1995), pp. 169-99; R. Judd, Common lands, common people: the origins of conservation in northern New England (Cambridge, MA, Harvard University Press, 1997), pp. 197-228.

${ }^{24} \mathrm{M}$. Woods, 'Deconstructing rural protest: the emergence of a new social movement', Journal of rural studies 19 (2003), pp. 309-25.

25 D.W. Linden, 'Dear Dad', Forbes 152 (6 Dec. 1993), pp. 98-99; M.A. Lipton and J. Campbell, 'Minding his beeswax', People 49 (13 July 1998), pp. 97-98; J. Tanner, 'From beehive to kitchen table to mass production', New York Times (16 Feb. 2003); S. Donovan, 'Roxanne Quimby: how I did it', Inc. 26 (Jan. 2004), pp. 76-78.

26 S. Young, 'Maine land purchased with eye on U.S. park', Bangor Daily News (10 July 2001).

27 A. Runte, National parks: the American experience, 3rd edn (Lincoln, University of Nebraska Press, 1997), pp. 114-26.

${ }^{28}$ L. Soares, All for Maine: the story of Governor Percival P. Baxter (Mount Desert, ME, Windswept House, 1995).

29 'Burt's Bees land conservation effort' (n.d., c. 2002, paper describing the company's land holdings mailed to the author from Burt's Bees, spring 2004).

30 Examples from the American West include: P. Walker and L. Formann, 'Whose landscape? A political ecology of the "exurban" Sierra', Cultural geographies 10 (2003), pp. 469-91; W.B. Beyers and P.B. Nelson, 'Contemporary development forces in the non-metropolitan West: new insights from rapidly growing communities', Journal of rural studies 16 (2000), pp. 45974; P.B. Nelson, 'Rural restructuring in the American West: land use, family and class discourses', Journal of rural studies 17 (2001), pp. 395-407.

31 'Questions and answers for hunters, anglers, snowmobilers and camp owners' (n.d., flyer published by RESTORE: The North Woods; author's collection). Also see 'Top 10 common questions and answers' (n.d., flyer published by RESTORE: The North Woods; author's collection).

32 For more on natural symbols, heritage and land use conflicts, see P. Solis, 'Water as rural heritage: reworking modernity through resource conflict in Edwards County, Kansas', Journal of rural studies 21 (2005), pp. 55-66.

33 R. Jerome and A. Driscoll, 'Green acres', People 56 (15 Oct. 2001), p. 73.

${ }^{34}$ On gateway communities, see J. Howe, E. McMahon and L. Propst, Balancing nature and commerce in gateway communities (Washington, DC, Island Press, 1997).

35 'Seven questions: Mother Nature is our inspiration', Drug and cosmetic industry 163 (July 1998), p. 18.

36 Young, 'Maine land purchased with eye on U.S. park'. Also see 'Putting her money where Maine's woods are', New York Times (6 Aug. 2001); Jerome and Driscoll, 'Green acres', pp. 7274.

37 See T. Chappell, The soul of a business: managing for profit and the common good (New York, Bantam, 1993).

38 Profiles of the company's history on its website, for example, continue to emphasize its homespun Maine roots. See http://www1.burtsbees.com

39 M. Domosh, 'Pickles and purity: discourses of food, empire and work in turn-of-the-century USA', Social and cultural geography 4 (2003), pp. 7-27.

40 M. Carpenter, 'Maine Woods: two visions, one town', Northern Sky News 26 (June 2004), p. 11. Other Monson residents expressed similar concerns to me during the summer of 2004. Some were cautiously optimistic that Quimby's visitors' centre might spark economic growth in the town, while others saw it as a power grab by a woman with seemingly unlimited capital. 
41 Carpenter, 'Maine Woods: two visions, one town', p. 12.

42 See D. Mitchell, Cultural geography: a critical introduction (Malden, MA, Blackwell, 2000); R.H. Schein, 'Normative dimensions of landscape', in C. Wilson and P. Groth, eds, Everyday America: cultural landscape studies after J.B. Jackson (Berkeley, University of California Press, 2003), pp. 199-218.

43 On the wise use movement, see J. McCarthy, 'Environmentalism, wise use and the nature of accumulation in the rural West', in B. Braun and N. Castree, eds, Remaking reality: nature at the millennium (London, Routledge, 1998), pp. 126-49; J. McCarthy and E. Hague, 'Race, nation, and nature: the cultural politics of "Celtic" identification in the American West', Annals of the Association of American Geographers 94 (2004), pp. 387-408. For related discussions about federal attempts to acquire property for national parks, see L.M. Dilsaver, Cumberland Island National Seashore: a bistory of conservation conflict (Charlottesville, University of Virginia Press, 2004). Although scoffed at by many, a recent state legislative proposal in Maine attempted to force the federal government to relinquish all its land holdings in the state: B. Trotter, 'Bill seeks to ban northern park', Bangor Daily News (22 Jan. 2005).

${ }^{44}$ Harrison, 'The Maine Woods National Park', pp. 26-28; J.P. Melcher, 'Away game: implications of "being from away" in Maine politics', Southern Maine review 1 (spring 2005), pp. 149-69.

45 B. MacQuarrie, 'At loggerheads over Maine Woods,' Boston Globe (21 Dec. 2003).

46 J. Holyoke, 'RESTORE opponents get boost from gov.-elect Baldacci', Bangor Daily News (10 Dec. 2002). Also see J. Clark, 'Forever private?', Down East 43 (Aug. 1996), p. 52.

${ }^{47}$ E.J. Conlogue, 'Fools and their money', Bangor Daily News (letter to the editor, 21 July 2001); K. Ryan, [no title], Bangor Daily News (letter to the editor, 16 July 2001); A.F. Smallwood, 'Let them eat cake', Bangor Daily News (letter to the editor, 20 July 2001); J. Simko, 'Querying Quimby', Bangor Daily News (letter to the editor, 15 Aug. 2002).

48 Carpenter, 'Maine Woods', p. 11; National parks 77 (May/June 2003), pp. 2-3; J. Harkavy, 'Celebs join effort for North Woods park', Bangor Daily News (5 May 2003).

49 M. Edgecomb, 'No-park army' rallies in protest', Bangor Daily News (30 June 2003); E. Stumpfel, 'RESTORE in the clouds', Bangor Daily News (letter to the editor, 7 May 2003).

50 K. Ward, 'Park opponents pull no punches in reply', Bangor Daily News (28/29 July 2001).

51 At the time that this argument was made, Burt's Bees was actually under new ownership and no longer formally supporting the MWNP proposal. This forum was hosted by the Portland Press Herald, but has since been removed from their website. For a copy of the discussion, contact the author.

52 E. Veyhl, 'Feudalist kingdom: what's really going on with Roxanne Quimby and her allies?' Magic City Morning Star (Millinocket, Maine) (18 Jan. 2004).

53 M.J. Kellett, 'Maine Woods National Park: the best way to restore the wild', Wild earth 10 (Summer 2000), pp. 60-64; B. McKibben, 'The Maine Woods', Patagonia Holiday 2002 (company catalogue).

54 P. Austin, 'Plum Creek sees green in Maine Woods', Northern Sky News 34 (Feb. 2005), pp. 1, $10-12$.

55 On the history of open access in Maine, see Judd, Common lands, common people, pp. 118119; Rolde, The interrupted forest, pp. 53-56.

56 M. Kellett, 'Preserving public access', Proposed Maine Woods National Park and Preserve, p. 6.

57 For empirical studies of tourism and social exclusion, see B. Harrison, 'Tourism, farm abandonment, and the "typical" Vermonter' Journal of bistorical geography 31 (2005), pp. 478-95; M. DeOliver, 'Historical preservation and identity: the Alamo and the production of a consumer landscape,' Antipode 28 (1996), pp. 1-23. 
58 RESTORE's park proposal does include a provision for a special 'preserve' of unspecified size where park visitors could engage in non-traditional activities such as hunting, trapping, and snowmobiling. Yet concessions like these come with no guarantee; they would need final approval from the NPS and the United States Congress, not from RESTORE.

59 M. Edgecomb, 'North Woods land sale troubles locals', Bangor Daily News (29 Aug. 2003); 'Buying Maine,' Bangor Daily News (2 Sep. 2003); M. Edgecomb, 'Quimby buy worries Mainers,' Bangor Daily News (26 Nov. 2003).

60 P. Austin, 'Roxanne Quimby purchases high priority 24,000 acre township east of Baxter Park', Maine Environmental News (24 Nov. 2003), http://www.meepi.org/files03/pa112403.htm; M. Edgecomb, 'Cosmetics maven buys T5 R8', Bangor Daily News (25 Nov. 2003).

61 M. Edgecomb, 'Quimby speaks on land deal', Bangor Daily News (5 Dec. 2003); T. Turkel, 'Looking for land', Portland Press Herald (7 Dec. 2003).

62 A. Diamon, 'New Mother Nature', Portland Phoenix (12-18 Dec. 2003).

63 'Keep ME Beautiful mission statement' (mailed to the author from the group's Portland, Maine office, fall 2004); J. Richardson, 'Landowner presses park proposal', Portland Press Herald (21 Jan. 2005).

64 R. Wilk, 'Consuming morality', Journal of consumer culture 1 (2001), p. 254.

${ }^{65}$ Sack, Place, modernity, and the consumer's world, pp. 22-23. 